\title{
Penerapan Kebijakan Anti-Dumping WTO sebagai Bentuk Tindakan Proteksi
}

\author{
Rizmawati Darmawan *, Irawati \\ Prodi Ilmu Hukum, Fakultas Hukum, Universitas Islam Bandung, Indonesia. \\ *rizmakey@gmail.com, ira.wati66@gmail.com
}

\begin{abstract}
Anti-dumping policy settings are clearly stated in the WTO - Agreement on Implementation of Article VI of The General Agreement on Tariffs and Trade 1994. The application of anti-dumping import duties as a protective measure is carried out by countries in order to protect their country's economy. This policy can be applied when a country meets several criteria in the classification of proven dumping as stated in the Article VI GATT 1994. Therefore, this study aims to find out the implementation and provisions of antidumping policy based on Agreement on Implementation of Article VI of The General Agreement on Tariffs and Trade 1994. This research method uses normative juridical approach with two concepts of comparison approach and case approach. By using descriptive analysis research specifications and data collection techniques through literature study. The results of this study concluded that based on Article VI anti-dumping policy can be enforced if at the time of the investigation process indicated the existence of dumping, the existence of material losses experienced in the domestic industry that produces similar goods, and the existence of a causal relationship between dumping and damage.
\end{abstract}

Keywords: Anti-Dumping, WTO - Agreement on Implementation of Article VI of The General Agreement on Tariffs and Trade 1994

\begin{abstract}
Abstrak. Pengaturan kebijakan anti-dumping secara jelas tercantum dalam WTO - Agreement on Implementation of Article VI of The General Agreement on Tariffs and Trade 1994. Pemberlakuan bea masuk anti-dumping sebagai tindakan proteksi dilakukan oleh negara-negara guna melindungi perekonomian negaranya. Kebijakan ini dapat diberlakukan ketika suatu negara memenuhi beberapa kriteria dalam klasifikasi terbukti adanya dumping yang tercantum dalam Article VI GATT 1994. Oleh karena itu penelitian ini bertujuan untuk mengetahui implemtasi dan ketentuan kebijakan anti-dumping berdasarkan Agreement on Implementation of Article VI of The General Agreement on Tariffs and Trade 1994. Metode penelitian ini menggunakan pendekatan yuridis normatif dengan dua konsep pendekatan perbandingan dan pendekatan kasus. Menggunakan spesifikasi penelitian deskriptif analisis dan teknik pengumpulan data melalui studi kepustakaan. Hasil penelitian ini menyimpulkan bahwa berdasarkan Article VI kebijakan anti-dumping dapat diberlakukan apabila pada saat proses investigasi terindikasi adanya dumping, adanya kerugian material yang dialami pada industri dalam negeri yang memproduksi barang sejenis, dan adanya hubungan sebab akibat antara dumping dan kerusakan.
\end{abstract}

Kata Kunci: Anti-Dumping, WTO - Agreement on Implementation of Article VI of The General Agreement on Tariffs and Trade 1994. 


\section{A. Pendahuluan}

Perdagangan adalah tatanan kegiatan yang terkait dengan transaksi barang dan/atau jasa didalam negeri dan melampaui batas wilayah negara dengan tujuan pengalihan hak atas barang dan/atau jasa untuk memperoleh imbalan atau kompensasi. Perdagangan sebagai salah satu sektor yang dapat membantu meningkatkan perekonomian suatu negara yang kemudian nantinya diharapkan dapat bersaing dengan negara lainnya melalui pasar global. Aktivitas perekonomian di era globalisasi tidak lagi fokus pada satu wilayah tertentu, melainkan menyebar di berbagai lokasi yang kemudian terhubung dalam satu rantai aktivitas ekonomi global yang dimulai dari produksi hingga konsumsi. Dengan adanya pasar global ini maka menciptakan daya saing, sehingga suatu negara dapat bekerjasama untuk membangun perekonomian melalui sistem perdagangan internasional. Kerjasama negara-negara dalam bidang perdagangan dilakukan dalam World Trade Organization disingkat sebagai WTO. Dengan adanya organisasi ini perdagangan antar negara akan didasari dengan hukum serta pengaturannya sesuai dengan perjanjian perdagangan. Terlebih lagi dengan banyak terjadinya pelanggaran perdagangan di kancah internasional yang kemudian berkembang menjadi persoalan persengketaan antar negara dan berakhir pada penyelesaian sengketa dalam forum WTO. Seperti munculnya tindakan dumping.

Dumping adalah suatu keadaan dimana barang-barang yang di ekspor oleh suatu negara ke negara lain dengan harga yang lebih rendah dari harga jual didalam negerinya sendiri atau nilai normal dari barang tersebut. Dalam ketentuan Pasal 2 ayat (1) Anti-Dumping Agreement, nilai normal merupakan harga dari barang sejenis di pasar pengekspor atau produsen. Nilai normal ini tentu saja harus mencapai angka wajar yang didalamnya sudah termasuk biaya transportasi, perbatasan perubahan nilai tukar dan lainnya antara barang yang di ekspor dengan barang yang sama di pasar eksportir. Tindakan curang dalam bentuk dumping dapat mengakibatkan kerugian pada pihak-pihak tertentu karena diskriminasi harga, dimana harga ekspor barang sejenis lebih rendah dari pada pasar domestik. Adanya praktik dumping yang marak terjadi, maka tidak sedikit negara yang menerapkan kebijakan anti-dumping guna melindungi perekonomiannya.

Anti-dumping bertujuan untuk mengurangi beban kerugian akibat praktek dumping. Pengaturan mengenai anti-dumping diatur dalam WTO sehingga tindakan yang berkaitan dengan anti-dumping merupakan tindakan legal yang dapat dilakukan suatu negara guna memperbaiki perekonomian yang dianggap terkena dampak praktik perdagangan yang tidak sehat.

\section{B. Landasan Teori}

Hukum Internasional merupakan hukum yang mengatur mengenai hubungan antar bangsabangsa atau the law of nations. Negara dan Organisasi dapat dikatakan sebagai subjek Hukum Internasional. Hak dan Kewajiban Negara, bahwa suatu negara untuk dapat dikatakan sebagai pribadi dalam hukum internasional adalah penduduk yang tetap, mempunyai wilayah (teritorial) tertentu, pemerintahan yang sah, serta kemampuan untuk mengadakan hubungan dengan negara lain. Organisasi Internasional memiliki peranan dalam Hukum Internasional untuk dapat melaksanakan hak dan kewajiban sesuai dengan kedudukannya. Organisasi Internasional dapat dilaksanakan atas dasar kesepakatan bersama oleh negara anggota melalui sebuah Perjanjian Internasional. Perjanjian Internasional dapat menjadi rujukan bagi negara-negara atau subjek Hukum Internasional lain untuk menyelesaikan berbagai permasalahan yang terjadi dalam hubungan internasional.

Negara anggota perjanjian memiliki kewajiban melaksanakan perjanjian baik secara ekstern maupun intern. Kewajiban secara ekstern, bahwa setiap negara dapat melaksanakan perjanjian dengan negara manapun asalkan tetap memperhatikan kewajiban dalam pelaksanaan perjanjian. Sedangkan kewajiban secara intern, bahwa negara memiliki hak dan wewenang eksklusif untuk dapat menentukan bentuk lembaga dan cara kerjanya dalam hal membuat Undang-Undang yang diinginkannya serta untuk dapat mematuhi aturan tersebut yang kemudian munculkan keterkaitan hubungan antara Hukum Nasional dan Hukum Internasional. Hubungan tersebut didasarkan pada aliran dualisme yang bersumber pada teori bahwa daya ikat Hukum Internasional bersumber pada kemauan negara, Hukum Internasional dan Hukum Nasional merupakan dua sistem atau perangkat hukum yang terpisah satu dari yang lainnya. 
Adapun aliran monisme, yang didasarkan atas pemikiran kesatuan dari seluruh hukum yang mengatur hidup manusia, dimana Hukum Nasional dan Hukum Internasional adalah dua bagian dari satu kesatuan yang besar dalam mengatur kehidupan manusia.

Perdagangan Internasional selalu mengalami perkembangan-perkembangan guna membangun perekonomian setiap negara yang sedikit banyak di latarbelakangi serta dipengaruhi oleh beberapa teori ekonomi. Adanya Teori Mercantilisme, bahwa Perdagangan Internasional sebagai instrumen kebijakan nasional. Teori Adam Smith, bahwa pengelolaan perekonomian negara dapat dilakukan dengan cara melaksanakan persaingan bebas tanpa adanya intervensi pemerintah. Teori David Ricardo, bahwa negara yang tidak memiliki keunggulan absolut bisa terlibat dalam Perdagangan Internasional yang menguntungkan. Prinsip dalam Perdagangan Internasional menjadi hal yang diperhatikan dalam pelaksanaan perdagangan, sehingga WTO sebagai organisasi Perdagangan Internasional mengatur prinsip tersebut, antaralain:

1. Prinsip Non-diskriminasi

Prinsip ini terdiri atas Most Favoured Nation (MFN) dan National Treatment Principle. Dalam Pasal I GATT menyatakan, MFN merupakan suatu kebijakan perdagangan yang harus dilaksanakan atas dasar non-diskriminatif, dimana setiap negara harus dapat diperlakukan sama antara satu negara dengan negara lainnya. Sedangkan dalam prinsip National Treatment, tercantum dalam Pasal III GATT bahwa produk dari suatu negara harus diperlakukan sama seperti halnya produk dalam negeri.

2. Prinsip Resiprositas

Dalam pelaksanaan Perdagangan Internasional dapat memberikan keuntungan bagi kedua pihak, bukan hanya menguntungkan salah satu pihak. Dalam Pasal II GATT menjelaskan bahwa adanya perlakuan timbal balik diantara sesama negara anggota WTO dalam kebijakan Perdagangan Internasional.

3. Prinsip Penghapusan Hambatan Kuantitatif

Dalam Pasal IX GATT bahwa larangan umum terhadap pembatasan atau bersifat kuantitatif yang berupa kuota tertentu atau pembatasan yang serupa, karena dianggap menghambat prinsip perdagangan bebas yang diterapkan berdasarkan larangan dan pembatasan proteksi terhadap produk domestik melalui pembatasan kuantitatif.

4. Prinsip Perdagangan yang Adil

Keadilan dalam Perdagangan Internasional merupakan praktek sosial internasional yang berkaitan dengan an international social practice of market reliance (ketergantungan pasar), bahwa praktek negara dalam Perdagangan Internasional itu bergantung pada pasar bersama, baik pasar barang, jasa, ataupun modal yang bertujuan untuk meningkatkan pendapatan nasional negara.

5. Prinsip Tarif Mengikat

Setiap negara anggota WTO harus dapat mematuhi besaran tarif yang sudah disepakati oleh negara-negara sesuai dengan pengaturan yang tercatat didalam peraturan WTO.

Dalam bidang perdagangan terdapat pengaturan Market Access (akses pasar) yang diciptakan untuk menentukan tarif yang diberlakukan oleh suatu negara untuk setiap barang atau jasa yang akan di impor. Akses pasar tersebut terkadang mengalami banyak kendala atau bahkan hingga terjadi pelarangan untuk masuk ke beberapa negara akibat permasalahan tarif. Pengaturan tersebut mencakup 3 hal. Pertama, bea masuk sebagai biaya keuangan yang berbentuk pajak yang diterapkan pada barang-barang pada waktu, dan/atau karena, impor barang-barang tersebut. Dalam penentuan bea masuk terhadap barang impor dilakukan melalui negosiasi tarif dan konsei tarif sebagai hasil dari negosiasi tarif, dimana kesepakatan tersebut bersifat tidak dapat dirubah. Kedua, hambatan kuantitatif perdagangan barang sebagai aturan yang membatasi jumlah atau kuantiti terhadap barang yang akan di impor atau di ekspor yang biasanya berbentuk kuota atau larangan terhadap impor ekspor secara umum. Ketiga, hambatan non-tarif perdagangan barang meliputi hambatan teknis terhadap tindakan sanitasi dan phitosanitasi, kurangnya transparansi, penerapan regulasi yang tidak adil, serta prosedur dan formalitas pajak.

Praktek dumping dalam GATT pada dasarnya merupakan praktek yang sangat akan 
berdampak buruk terhadap suatu negara dan memungkinkan akan merugikan bagi sistem pasar internasional. Bagi negara yang merasa dirugikan akibat dumping dapat mengajukan keberatan hingga dijatuhi anti-dumping duty sesuai dengan selisih harga normal dan harga dumping yang disebut dengan margin dumping. Untuk dapat mengetahui margin dumping, maka diperlukan penentuan harga normal, harga ekspor, dan perbandingan antara keduanya.

1. Harga Normal

Harga normal ini menjadi tolak ukur apakah produk suatu negara mengalami dumping dengan cara melihat apakah harga produk yang dijual mencapai harga normal. Dalam penentuan harga normal maka penjulaan harus dapat dilaksanakan secara wajar.

2. Harga Ekspor

Biasanya harga ekspor didapatkan ketika barang tersebut dijual kepada pembeli secara independen, sehingga ketika barang tersebut dijual maka akan muncul harga ekspor sebagai tolak ukur dalam sistem jual beli Perdagangan Internasional ataupun jika sulit untuk dilaksanakan maka suatu negara dapat memberikan harga ekspor sesuai dengan standar daripada produk barang itu sendiri, serta memberikan harga ekspor secara wajar agar tidak menimbulkan kerugian sepihak.

3. Perbandingan Harga Normal dan Harga Ekspor

Perbandingan harga keduanya perlu dilakukan secara wajar. Perbandingan ini harus dapat dilakukan pada tingkat perdagangan yang sama, dan sehubung dengan itu pula perbandingan dapat dilakukan hanya pada waktu yang sama atau pada saat waktu yang berdekatan ketika melakukan penjualan.

\section{Hasil Penelitian dan Pembahasan}

\section{Ketentuan Anti-Dumping Berdasarkan Agreement on Implementation of Article VI of the General Agreement on Tariffs and Trade 1994}

Ketentuan khusus tentang anti-dumping yang terdapat pada Agreement On Implementation of Articcle VI of GATT 1994 atau Anti-Dumping Code 1994 yang dibentuk sebagai salah satu sumbangsih pengaturan dalam perundingan Uruguay Round. Dalam pasal tersebut dijelaskan bahwa apabila salah satu pihak dalam Perdagangan Internasional terutama ketika melakukan perjanjian ekspor impor menyadari adanya dumping pada suatu barang dari negara lain yang masuk kenegaranya dengan harga lebih rendah dari nilai normal, maka dapat melakukan perlindungan dengan menetapkan bea masuk anti-dumping sebagai tindakan untuk perlindungan meminimalisir kerugian materi yang dapat diderita oleh industri dalam negeri atau secara material dapat menghambat pembangunan industri dalam negeri.

Penentuan mengenai nilai normal dan nilai ekspor menjadi pertimbangan dalam mekanisme pengenaan anti-dumping. Perbandingan antara nilai normal dan nilai ekspor ini harus dapat dilakukan tanpa ada diskriminasi harga. Untuk menciptakan margin dumping dalam Article 2.4.2 Anti-Dumping Agreement, dapat ditetapkan berdasarkan perbandingan nilai normal rata-rata tertimbang dengan nilai ekspor rata-rata tertimbang secara keseluruhan.

Dalam menerapkan kebijakan anti-dumping perlu dilakukan pembuktian adanya dumping. Terbukti adanya dumping dilihat dari penentuan barang sejenis yang menjadi pertimbangan dalam proses penyelidikan tahap awal. Penentuan barang sejenis ini menjadi perbandingan dengan barang dumping pada industri importer yang nantinya dapat menentukan apakah terbukti adanya kerusakan atau tidak. Kriteria suatu barang mengalami kerusakan disebabkan karena adanya kerusakan material terhadap industri dalam negeri, adanya ancaman kerusakan material terhadap industri dalam negeri, dan terjadi kekurangan material atas pendirian industri dalam negeri, yang dalam hal ini tidak diatur secara jelas dalam Anti-Dumping Agreement.

1. Kerusakan material terhadap industri dalam negeri. Kerusakan ini diatur dalam Article 3.1 Anti-Dumping Agreement, dalam menentukan kerusakan dengan memperhatikan dua hal, yaitu volume impor barang yang di dumping serta efek atas harga produk sejenis di pasar domestik karena nantinya akan berpengaruh terhadap harga produk sejenis di pasar domestik, sehingga tingkatan volume barang impor yang di dumping perlu diperhatikan. Dan dampak konsekuensi dari impor tersebut terhadap produsen dalam negeri.

2. Adanya ancaman kerusakan material terhadap industri dalam negeri. Kerusakan dapat 
dibuktikan serta dijelaskan secara rinci dan dapat dipertangungjawabkan kebenarannya, sebab ancaman tersebut juga akan memberikan dampak negatif berupa kerugian pada industri domestik suatu negara. dalam menentukan adanya kerusakan harus didasarkan pada bukti-bukti yang positif serta melakukan pemeriksaan secara objektif. Sehingga bagi suatu negara yang merasa sudah terbukti bahwa adanya kerusakan pada industri domestik akibat adanya kerusakan pada industri domestiknya dapat mengambil tindakan perlawanan dengan memberlakukan kebijakan anti-dumping untuk melindungi industri dalam negeri.

dan terjadi kekurangan material atas pendirian industri dalam negeri, yang dalam hal ini tidak diatur secara jelas dalam Anti-Dumping Agreement.

Menentukan hubungan sebab akibat antara dumping dan kerusakan juga menjadi pertimbangan untuk dapat tidaknya negara menerapkan kebijakan anti-dumping. Dalam Article 3.5 Anti-Dumping Agreement menjelaskan megenai faktor pembuktian sebab akibat antara barang yang di dumping dengan kerugian yang diderita oleh industri dalam negeri. Faktor tersebut meliputi:

1. volume dan harga impor yang dijual dengan harga dumping;

2. kontraksi pada permintaan atau perubahan pada pola konsumsi;

3. praktek penghambat perdagangan dari dan persaingan antara produsen asing dan lokal;

4. perkembangan teknologi;

5. performa ekspor dan produktivitas dari industri domestik.

Terjadinya kerusakan pada barang tidak semua diakibatkan karena dumping, sepanjang kerusakan dapat dibuktikan secara jelas dan mengarah pada dumping, maka hubungan sebab akibat antara keduanya sudah terpenuhi.

\section{Implementasi Ketentuan Anti-Dumping Berdasarkan Agreement on Implementation of Article VI of the General Agreement on Tariffs and Trade pada Kasus Bea Masuk Anti-Dumping Australia Terhadap Ekspor Kertas Salinan A4 Indonesia}

Setiap negara yang menerapkan kebijakan anti-dumping harus membuktikan adanya dumping, terbukti adanya kerusakan terhadap barang sejenis di negara pengimpor, dan hubungan sebab akibat keduanya. Penentuan dumping secara jelas harus mengetahui margin dumping yang ditetapkan berdasarkan nilai normal dan nilai ekspor.

Pada kasus Australia dan Indonesia dalam bidang kertas salinan A4, dimana Australia melayangkan klaim adanya Particular Market Situastion (PMS) atau situasi pasar tertentu di industri pasar Indonesia terurtama dibidang industri kayu. Situasi pasar tertentu ini berpengaruh pada ketentuan nilai normal dan nilai ekspor yang akan dibangun. Hal tersebut menjadikan Australia memberlakukan kebijakan anti-dumping. Ketentuan anti-dumping yang diberlakukan oleh Australia ini tidak sesuai dengan pasal terkait karena Australia tidak menggunakan nilai penjualan pasar domestik untuk menentukan nilai normal. Berkaitan dengan hal tersebut, dalam panel kasus kertas salinan A4 Australia dan Indonesia memperhatikan beberapa faktor dalam menentukan nilai normal karena situasi di pasar ekspor seperti:

1. apakah terdapat harga yang rendah secara artifisial;

2. apakah ada kondisi lain di pasar yang membuat penjualan di pasar tidak cocok untuk digunakan dalam menentukan harga.

Dalam menilai adanya situasi pasar tertentu karena pengaruh pemerintah, dapat ditentukan melalui apakah keterlibatan pemerintah tersebut dalam pasar domestik telah mengubah kondisi pasar secara material. Jika kondisi pasar telah terdistorsi secara material, maka harga domestik mungkin akan secara artifisial ikut rendah atau tidak secara substansial sama dengan kondisi pasar yang kompetitif. Selain itu, rendahnya harga diakibatkan oleh pengaruh pemerintah terhadap biaya input. Campur tangan pemerintah terhadap biaya input dapat dilihat pada kondisi pasar sejauh mana harga domestik tidak dapat diberlakukan kembali pada kondisi pasar yang kompetitif. Keikut sertaan pemerintah dalam industri domestik kayu bulat Indonesia dapat menjadi salah satu penyebab rendahnya harga secara artifisial.

Untuk menentukan nilai normal dapat memperhatikan pertimbangan penjualan. Mengacu pada Article 2.2 bahwa penjualan produk sejenis yang ditujukan untuk konsumsi di pasar 
domestik negara pengekspor biasanya dianggap sebagai jumlah yang cukup untuk penentuan nilai normal jika penjualan tersebut merupakan 5\% atau lebih dari penjualan produk dengan pertimbangan kepada anggota pengimpor. Sementara penghitungan nilai normal yang dilakukan Australia melalui perbandingan atas nilai ekspor bubur kertas yang berasal dari Brazil, Amerika Selatan, Cina dan Korea karena dinilai bahwa industri kertas Indonesia disinyalir adanya siatuasi pasar tertentu sehingga penentuan nilai normal tidak dapat ditentukan berdasarkan perbandingan harga dari PT Indah Kiat Pulp and Paper dan PT Pindo Deli Pulp and Paper.

Pengaruh situasi pasar tertentu pada pasar Indonesia untuk kertas salinan A4 semata-mata karena adanya penurunan biaya pembelian atau pembuatan bubur kertas, sebab harga daripada produk tersebut sebagai input penting bagi industri domestik Indonesia. Pada kenyataannya yang menyebabkan harga kertas salinan A4 di Indonesia mencapai harga rendah karena dipengaruhi oleh penurunan biaya pulp. Tindakan Australia yang mengabaikan harga untuk menentukan nilai normal terhadap PT Indah Kiat dan PT Pindo Deli dan secara tidak berhak menggunakan perbandingan nilai ekspor dari negara lain. Atas dasar tersebut, tidak ditemukannya adanya tindakan dumping akibat dari situasi pasar tertentu pada industri kertas Indonesia yang menjadikan syarat berlakunya kebijakan anti-dumping yang dilakukan Australia terhadap kertas salinan A4 Indonesia tidak dapat diberlakukan.

Sedangkan indikasi adanya kerusakan material yang dialami industri dalam negeri pada negara pengimpor yang memproduksi barang sejenis menyatakan bahwa indikasi dumping tidak di temukan pada produk kertas salinan A4 Indonesia, sehingga peningkatan volume impor dan penurunan ekspor Australia ini semata-mata disebabkan oleh meningkatnya nilai mata uang dollar Australia yang berpengaruh pada defisit perdagangan di sektor kertas pada periode 2013 hingga 2014.

\section{Kesimpulan}

Berdasarkan pembahasan dalam penelitian ini, peneliti menyimpulkan beberapa hasil penelitian sebagai berikut:

Pengenaan bea masuk anti-dumping tidak semata-mata diberlakukan begitu saja. Kriteria diberlakukannya kebijakan anti-dumping sesuai dengan perjanjian anti-dumping yaitu, jika terbukti adanya dumping, adanya industri lokal yang memproduksi barang sejenis di negara pengimpor yang mengalami kerusakan atau injury, dan adanya hubungan sebab-akibat antara dumping dan kerusakan.

Ketiga kriteria tersebut tidak dapat dibuktikan oleh Australia. Pembuktian Australia tentang adanya dumping akibat terjadinya particular market situation pada industri bahan baku kayu tidak sesuai dengan Article 2.2 Anti-Dumping Agreement. Perbandingan nilai normal dan nilai ekspor pada kertas salinan A4 Indonesia juga dilakukan oleh Australia dengan mengabaikan harga domestik PT Indah Kiat dan PT Pindo Deli. Selain itu, dalam membangun nilai normal Australia tidak memperhatikan pengaturan dalam article 2.2.1.1 dengan mengabaikan biaya yang dicatat oleh PT Indah Kiat dan PT Pindo Deli dalam pembukuan bubur kayu kertas untuk eksportir Indonesia. Kerusakan yang diakibatkan karena barang impor tidak terlihat, sehingga tidak menciptakan adanya hubungan sebab-akibat antara dumping dan kerusakan. Sehingga dalam hal ini Australia tidak dapat memberlakukan bea masuk anti-dumping terhadap kertas salinan A4 Indonesia.

\section{Daftar Pustaka}

[1] Undang-Undang Nomor 7 Tahun 2014 tentang Perdagangan.

[2] Report Panel Australia-Anti-Dumping Measures on A4 Copy Paper.

[3] The Agreement on Implementation of Article VI of the General Agreement on Tarifs and Trade 199.

[4] Tri Cahya Utama, dkk, :Pencegahan Praktik Kejahatan Ekonomi Dalam Perdagangan BebasOrigin Fraund Dalam Industri Mebel Kayu Di Jepara”, Jurnal Ilmu Sosial, Vol.15, No.1, Januari 2016.Arikunto, Suharsimi. 2006. Prosedur Penelitian Suatu Pendekatan Praktek. Jakarta: Rineka Cipta.

[5] Cristophorus Barutu, Ketentuan Anti Dumping Subsidi dan Tindakan Pengamanan (safe 
guard) Dalam GATT dan WTO, PT Citra Aditya Bakti, 2007.

[6] Muhajir La Djanudin, "Mekanisme Penyelesaian Sengketa Dumping Antar Negara", 2013.

[7] Hari Tjahjono, “Anti Dumping di Indonesia”, Opinio Jurnal, 2010.

[8] Mochtar Kusumaatmadja, Etty R. Agoes, Pengantar Hukum Internasional, PT. Alumni, Bandung, 2003.

[9] Danel Aditia Situngkir, "Terikatnya Negara Dalam Perjanjian Internasional”, Jurnal Ilmu Hukum, Volume 2, Nomor 2, April 2018.

[10] Jean Elvardi, "Perjanjian Internasional Tentang Kesepakatan Masyarakat Ekonomi ASEAN dan Tiongkok Dalam Hukum Nasional Indonesia”, De Lega Lata, Vol.2, No.1, Januari-Juni 2017.

[11] Peter Van Den Bosche, Daniar Matakusumah, Joseph Wira Koesnaidi, Pengantar Hukum WTO (World Trade Organization), Yayasan Obor Indonesia, Jakarta, 2020.

[12] Nita Anggraeni, "Dumping dalam Perspektif Hukum Dagang Internasional dan Hukum Islam”, Jurnal Pemikiran Hukum Islam Mazahib, Vol.14, No.2, Desember 2015. 